\title{
Empirical testing of trade off theory and pecking order theory on companies in the LQ45 index on the Indonesian stock exchange
}

\author{
A.N. Octavia ${ }^{1}$, G.S. Wicaksono ${ }^{2}$, D.P. Sari ${ }^{3}$, V.V. Mambay ${ }^{4}$ \\ Faculty of Economics and Business, Diponegoro University, Indonesia ${ }^{1234}$ \\ \{ayunurafnioctavia@yahoo.co.id\}
}

\begin{abstract}
Determinant of the optimal capital structure is often debated among practitioners and academics. This debate has led to several theories about capital structure which attempt to explain the best funding structure between debt and equity of the companies. This study aims to test the trade-off theory and the pecking order theory of capital structure of the LQ45 index company in Indonesia. This study used pooled cross sectional system who obtained 104 as observational data. To analyze the data used SPSS 23 Version, using multiple linear regression models. The results show that firm size has no significant effect on capital structure, while CR and ROA has negative effect on capital structure. This study concludes that companies in LQ45 index prefer to use internal funds more than external funds, that means the pecking order theory is proven in this study.
\end{abstract}

Keywords: trade-off theory, pecking order theory, firm size, liquidity, profitability, capital structure

\section{Introduction}

Determinant of the optimal capital structure is often debated among practitioners and academics. This debate is very important because the optimal mix of capital structure can have an effect on increasing firm value, so the theories about capital structure emerge that attempt to explain the best funding structure between debt and equity because each funding has different financial consequences. There are two main theories about capital structure, namely pecking order and trade-off theory. Many studies have inconsistent result. [1]; [2] [3] [4][2]; [5]; [6] so this research will test the trade off and pecking order theory. In 1973, Kraus and Litzenberger found that there is an optimal capital structure. It attempt by balancing the benefits of reducing taxes on debt usage against bankruptcy costs. The company will be indebted up to a certain level where the tax deduction is from the additional debt equals the financial distress cost. The financial distress cost are consist of bankruptcy costs and increased agency costs as a result of decreased corporate credibility. Based on this theory, the company will maintain a targeted capital structure with the aim of maximizing firm value [7].

Meanwhile pecking order theory introduced by Myers in 1984 when considering the problem of information asymmetry. A high growth company with a low operating cash flow will require a lot of funding and may increase debt, while a company that has high returns will prefer internal financing and reduce debt. In the pecking order theory model, there is an order 
in funding where the company will prioritize internal funding from retained earnings, then use external funds in the form of debt if needed, and as the last alternative is the issuance of new shares [8]. The object of this research is the LQ45 index company because LQ45 shares have high market capitalization, growth prospects and good financial conditions. In addition, LQ45 is a safe stock to own because the fundamentals of the stock's performance are good, so from a risk point of view the LQ45 stock group has the lowest risk compared to other stocks. In addition, this research will focus on non-financial companies because the main activitiy from financial companies are collecting funds from public where the funds are going to be debts for the company. Therefore, the financial companies in financial statements have greater debt than non-financial companies.

The aim is to test LQ45 companies used the trade off or pecking order theory in their funding policies. The test is by looking at several factors who assume to affect the capital structure such as company size, liquidity and profitability. The research will be conducted at the LQ45 index company for the 2014-2017 period.

\section{Literature Review}

\subsection{Trade Off theory}

Trade off theory is a development theory of Modigliani and Miller, this theory introduced by Miller (1977) which stated the optimal capital structure implementation can be maximized by balancing the cost and benefits of debt. The company will continue to increase debt when the tax reduction benefits are still higher than the estimated agency costs but the increase in debt must be stopped when the tax reduction on the use of debt is lower than the agency costs [9]. The company value can be supported by proper funding structure management. Trade off theory related between taxes, the risk of bankruptcy and the use of debt. In this case, debt acts as a tax protector because it can reduce the amount of tax that must be paid by the company in the form of interest payments to those who provide debt [10].

\subsection{Pecking Order Theory}

Myers (1984) who first initiated the pecking order theory when considering the problem of asymmetry information between managers and stakeholders. This theory predicts that company will prefer to use internal funding if they have sufficient funds or the company is able to generate profits. Then the company will prefer debt over equity if external funding is needed [11]. If a company uses internal funding to experience a financial deficit, they will prefer to use safe funding namely debt rather than equity because it will be more risky [12].

\subsection{Hypotesis Development}

\section{a) The effect of company size on DER}

Company size describes the size of a company which can be seen from its total assets, stock market value, and sales stability. Large companies are tend to easily get external funds because they have a fairly good reputation among investors. Research conducted by [13]; [14]; [15], found a positive influence on company size with DER supporting trade-off theory. In other theory, a company with a large size will be more diversified and able to get high profits, so that large companies will like internal funding from retained earnings because of the lowest costs 
and risks. Research by [16]; [17] found that firm size and DER supports the pecking order theory.

H1a: Firm size has a positive effect on DER

H1b: Firm size has a negative effect on DER

\section{b) The effect of CR on DER}

CR shows that the company's ability to immediately repay debt at maturity will gain creditor trust to obtain debt, the higher CR value will make the higher debt. Research conducted by [18] found a positive influence between the two supporting trade off theory.

Meanwhile according to the pecking order theory, companies with high $\mathrm{CR}$ will use internal funds because they have more current assets that can be used for investment. The higher level of liquidity show that company performance is good and companies with good performance are able to generate large profits so that they can be used to fund investments. Research conducted by [19]; [20]; [21] found the negative effect of CR on DER

H2a: CR has a positive effect on DER

$\mathrm{H} 2 \mathrm{~b}$ : CR has a negative effect on DER

\section{c) The effect of ROA on DER}

ROA show the ability to achieve profit. Companies with high ROA are likely to generate with high profits. In pecking order, companies will like internal funds if they have high profits. The higher profitability show that the company has the opportunity to save more retained earnings to be used as funding. Research conducted by [22]; [23]; [24] found that profitability has a negative effect on DER. Meanwhile according to the trade off theory, companies with high profits will also have high tax rates. The tax payments of the company will owe to the point of balance between the costs and benefits obtained. Research conducted by [25], [26], [27] found company support trade-off theory.

H3a: ROA has a positive effect on DER

H3b: ROA has a negative effect on DER

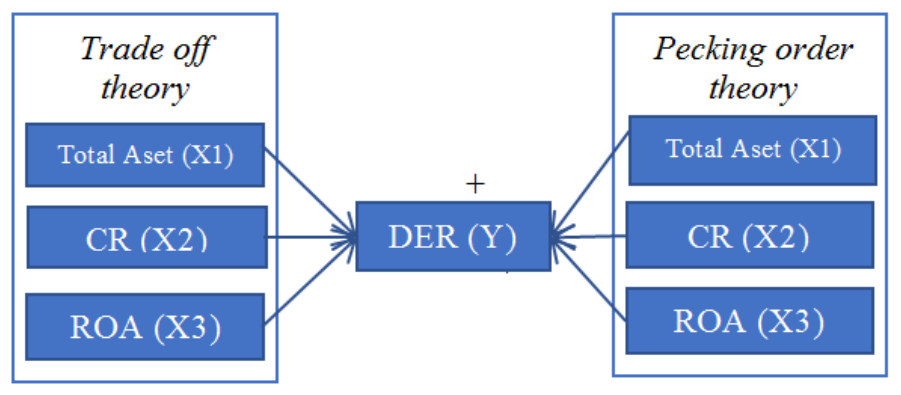

Fig.1. Conceptual Framework

\section{Research Methodology}

The selection sample was made based on the purposive sampling method with certain criteria. The criteria sample are companies who listed in 2014-2017 on LQ45 index and are not 
delisting, also the company publishes financial reports and in rupiah currency, most recently not a financial company. So, the sample is 26 companies with 104 observational data.

The test method using multiple linear regression analysis, the data analyzed of this study is secondary data who has passed the classical assumption test which will then be tested on T, F test and determination test.

The formula for the regression equation is:

$\mathrm{DER}=\square \square \square \square \square$ Size $+\square_{\square} \mathrm{CR}+\square_{3} \mathrm{ROA}+\mathrm{e}$

The results of statistical descriptive tests using SPSS can be seen in the following table.

Table 1. Descriptive Statistics

\begin{tabular}{cccccc}
\hline & $\mathbf{N}$ & Min & Max & Mean & Std. Deviation \\
\hline DER & 104 &, 13 & 5,11 & 1,1586 &, 94162 \\
SIZE & 104 & 30,00 & 33,00 & 31,1250 &, 89970 \\
CR & 104 &, 48 & 9,71 & 1,9859 & 1,27948 \\
ROA & 104 &, 49 & 40,18 & 8,1186 & 6,97109 \\
Valid N & 104 & & & \\
\hline \multicolumn{5}{c}{ Source : SPSS output, 2018 }
\end{tabular}

Table 1 , the minimum DER value of 0.13 percent is owned by PT. Indocement Tunggal Prakasa Tbk in 2016 and a maximum DER of 5.11 percent owned by PT. Housing Development Tbk in 2014. The minimum company size value of 30.00 is owned by PT. PP London Sumatera Tbk in 2014 and the maximum company size of 33.00 is owned by PT. Astra International Tbk in 2017. The minimum CR value of 0.48 is owned by PT. Jasa Marga Tbk in 2015 and a maximum CR of 9.71 are owned by PT. Media Nusantara Citra Tbk in 2014. The minimum ROA value of 0.49 is owned by PT. Lippo Karawaci Tbk in 2017 and a maximum ROA of 40.18 owned by PT. Unilever Indonesia Tbk in 2014.

\subsection{Measurement of Variables}

\section{a) Debt to Equity Ratio}

The dependent variable is the DER, which compares the total debt with total equity (Hussainey and Aljifri, 2012).

$\mathrm{DER}=\frac{\text { Total Liability }}{\text { Total Equity }} \times 100 \%$

b) Size

Size is proportion of total assets owned by a company. Size is proxied by $\ln$ total assets (Chadha, 2016). Size is formulated as :

Size $=\operatorname{Ln}($ TotalAssets $)$

\section{c) Current Ratio}


The current ratio is one of the ratios used to measure company liquidity (Basu, 2015). CR is systematically formulated as follows

$\mathrm{CR}=\frac{\text { Current Assets }}{\text { Current Liabilities }} \times 100 \%$

\section{d) Return on Assets}

Profitability is measured by ROA), which compares earnings after interest and taxes with total assets (Alhashel, 2015). ROA is systematically formulated as follows.

$\mathrm{ROA}=\frac{\text { Net Income }}{\text { Total Assets }} \times 100 \%$

\section{Findings}

The results have passed the classical assumption tests. K-S test, the significance value is 0.386 , these results indicate that the variables are normally distributed because it is greater than 0.05 , thus the processed data meets the assumption of normality. The multicollinearity test, Tolerance value of the independent variable is below to 1 , namely $0.956,0.977,0.971$ and the VIF value shows that no one independent variable has a value of more than 10 , namely $1.046,1.024,1.030$. This shows that the resulting regression model does not occur multicollinearity between the independent variables.

In this study, heteroscedasticity test use scatterplot graph and heteroscedasticity does not occur in the regression model. The autocorrelation test results obtained a DW value of 2.162, an $\mathrm{N}$ value of 104 and the number of independent variables as many as 3 variables, then the $\mathrm{dl}$ value is 1.62 and du is 1.74. the D-W coefficient (2.162) between DU (1.74) to 4-DU (2.26), so it is concluded that model doesn't have autocorrelation problems. T-test is described as follow:

Table 2. T-Test

\begin{tabular}{|c|c|c|c|c|c|c|}
\hline & \multirow[t]{2}{*}{ Model } & \multicolumn{2}{|c|}{ Unstandardized } & \multirow{2}{*}{$\begin{array}{c}\text { Standardized } \\
\text { Beta }\end{array}$} & \multirow[t]{2}{*}{$\mathbf{t}$} & \multirow[t]{2}{*}{ Sig. } \\
\hline & & B & Std. Error & & & \\
\hline \multirow[t]{4}{*}{1} & (Constant) & 10,54 & 6,641 & & 1,587 &, 116 \\
\hline & SIZE & $-2,77$ & 1,924 &,- 102 & $-1,44$ &, 152 \\
\hline & $\mathrm{CR}$ &,- 952 & , 109 &,- 612 & $-8,76$ &, 000 \\
\hline & $\mathrm{ROA}$ &,- 344 &, 065 &,- 368 & $-5,24$ &, 000 \\
\hline
\end{tabular}

Multiple regression analysis can be seen that the constant value is 10,542 coefficients for the independent variables $\mathrm{X} 1=-2,778, \mathrm{X} 2=-0,952$ and $\mathrm{X} 3=-0,344$ so that the regression equation obtained is as follows:

$\mathrm{Y}=10,542-2,778$ Size $-0,952 \mathrm{CR}-0,344 \mathrm{ROA}+\mathrm{e}$

The value of company size has a negative direction of -2.778 which is significant at 0.152 which is greater than 0.05 . This shows that $\mathrm{H} 1 \mathrm{a}$ and $\mathrm{H} 1 \mathrm{~b}$ are rejected and it proves that firm size doesn't have a significan effect on DER. The CR value has a negative direction of -0.952 significant at 0.00 . This shows that $\mathrm{H} 2 \mathrm{a}$ is rejected and $\mathrm{H} 2 \mathrm{~b}$ is accepted. So that $\mathrm{CR}$ has a significant negative effect on DER supporting the pecking order theory. The ROA value has a 
negative direction of -0.344 significant at 0.00 . This shows that $\mathrm{H} 2 \mathrm{a}$ is rejected and $\mathrm{H} 2 \mathrm{~b}$ is accepted. So that ROA on DER supporting the pecking order theory.

Table 3. Regression Analysis Result

\begin{tabular}{cccccc}
\hline Model & Sum of Squares & df & Mean Square & F & Sig. \\
\hline Regression & 33,111 & 3 & 11,037 & 36,599 &, 000 \\
Residual & 30,157 & 100 &, 302 & & \\
Total & 63,268 & 103 & & \\
\hline \multicolumn{6}{c}{ Source: SPSS Output, 2018 }
\end{tabular}

The next test is the F test by comparing the F-count with the F-table. The F-table is obtained by 2.70 from $(\mathrm{df} 1 / \mathrm{N} 1=3)$ and $(\mathrm{df} 2 / \mathrm{N} 2=100)$. The results of the F-count is 36.559> $2.70(\mathrm{~F}-$ table value) so that the independent variables jointly affect dependent variable. Furthermore, the test results of the coefficient of determination are as follows

Table 4. Coefficient of Determination

\begin{tabular}{lllll}
\hline Model & R & R Square & Adjusted R Square & Std. Error of the Estimate \\
\hline 1 &, $723^{\text {a }}$ &, 523 &, 509 &, 54915 \\
\hline \multicolumn{5}{c}{ Source: SPSS Output, 2018}
\end{tabular}

The table above shows the adj. $\mathrm{R}^{2}$ is 0.509 . It shows that $50.9 \%$ of the capital structure variable can be explained by company size variables, CR and ROA. Meanwhile the $49.1 \%$ influenced by variables outside the study.

\section{Conclusion and Recommendation}

Based on the results of the research obtained, hypothesis $1 \mathrm{a}$ and hypothesis $1 \mathrm{~b}$ are rejected, so company size does not significantly influence DER. Furthermore, hypothesis $2 \mathrm{a}$ is rejected and $\mathrm{H} 2 \mathrm{~b}$ is accepted, that means there is a negative effect between CR on DER. These results support the pecking order theory. Furthermore, hypothesis $3 \mathrm{a}$ is rejected and $\mathrm{H} 3 \mathrm{~b}$ is accepted so that means there is negative effect between ROA on DER. These results support the pecking order theory. It can be conclude that LQ45 companies applies pecking order theory on their funding structure

This study has several limitations, namely only using a time period of four years, so that it is expected that further research can be use to longer period of time in order to see the consistency of the influence of independent variables on DER. The object of this research is only on the LQ45 index which amounts to 45 companies so that it produces a small sample, for further research it is hoped that it can use a wider sample such as manufacturing companies or companies listed on the IDX so as to allow better results from this study. In this study, the value of $\mathrm{R}^{2}$ is only $50.9 \%$ with the variables of company size, liquidity and profitability. It is hoped that further research can add more variables to increase the coefficient of determination

\section{References}

[1] G. Gerardo, 'The determinants of capital structure in Peru', vol. 27, no. 3, pp. 341-354, 2014, doi: 10.1108/ARLA-01-2014-0007.

[2] R. Zhang and Y. Kanazaki, 'Testing static tradeoff against pecking order models of capital structure in Japanese firms', Int. J. Account. Inf. Manag., vol. 15, no. 2, pp. 24- 
36, 2007, doi: 10.1108/18347640710837335.

[3] M. Azeem, N. Ahmed, and A. Ahmad, 'www.econstor.eu', 2015.

[4] S. Jarallah, A. S. Saleh, and R. Salim, 'Examining pecking order versus trade - off theories of capital structure : New evidence from Japanese firms', no. February, pp. 1-8, 2018, doi: 10.1002/ijfe.1657.

[5] D. Borgia and A. Newman, 'The influence of managerial factors on the capital structure of small and medium-sized enterprises in emerging economies Evidence from China', 2012, doi: 10.1108/17561391211262148.

[6] B. M. Arqawi and W. J. Bertin, 'The impact of product warranties on the capital structure of Australian firms', no. June 2013, 2014, doi: 10.1177/0312896213496258.

[7] S. Chadha and A. K. Sharma, 'Determinants of capital structure : an empirical evaluation from India', vol. 12, no. 1, pp. 3-14, 2015, doi: 10.1108/JAMR-08-2014-0051.

[8] A. De Jong, M. Verbeek, and P. Verwijmeren, 'Firms' debt - equity decisions when the static tradeoff theory and the pecking order theory disagree', J. Bank. Financ., vol. 35, no. 5, pp. 1303-1314, 2011, doi: 10.1016/j.jbankfin.2010.10.006.

[9] S. Buvanendra, P. Sridharan, and S. Thiyagarajan, 'Role of Country-specific Factors on Capital Structure Decision - Evidence from Sri Lankan Listed Firms', 2016, doi: 10.1177/0972150916630454.

[10] R. S. Chirinko and A. R. Singha, 'Testing static tradeo ! against pecking order models of capital structure : a critical comment \&', vol. 58, pp. 417-425, 2000.

[11] F. Sardo and Z. Serrasqueiro, 'Does dynamic trade-off theory explain Portuguese SME capital structure decisions?', J. Small Bus. Enterp. Dev., vol. 24, no. 3, pp. 485-502, 2017, doi: 10.1108/JSBED-12-2016-0193.

[12] G. Morri and F. Cristanziani, What determines the capital structure of real estate companies? An analysis of the EPRA / NAREIT Europe Index. 2009.

[13] A. Newman, S. Gunessee, and B. Hilton, 'i s b j Applicability of financial theories of capital structure to the Chinese cultural context: A study of privately owned SMEs', 2010, doi: $10.1177 / 0266242610370977$.

[14] Z. A. Khan and B. Nafees, 'Static Trade-off theory or Pecking order theory which one suits best to the financial sector. Evidence from Pakistan .', vol. 5, no. 23, pp. 131-141, 2013.

[15] F. Issues, 'The Determinants of Capital Structure ':, vol. 5, no. 1, pp. 158-171, 2015.

[16] L. Pacheco and F. Tavares, 'Capital structure determinants of hospitality sector SMEs', Tour. Econ., vol. 23, no. 1, pp. 113-132, 2017, doi: 10.5367/te.2015.0501.

[17] N. R. Nejad, 'Multilevel Determinants of Capital Structure : Evidence from Malaysia', 2015, doi: 10.1177/0972150914564274.

[18] P. Sharma and S. Paul, 'Does Liquidity Determine Capital Structure ? Evidence from India', vol. 2, no. 2010, pp. 84-95, 2015, doi: 10.1177/0972150914553510.

[19] S. H. S. Roerink, 'Testing the static trade-off theory and the pecking order theory of capital structure: Evidence from Dutch listed firms', 2014.

[20] H. Purohit, 'Determinants of Capital Structure in Indian Manufacturing Sector', 2012, doi: $10.1177 / 2319510 X 1200800306$.

[21] W. A. Adesola, 'TESTING STATIC TRADEOFF THEORY AGAINST PECKING ORDER MODELS OF CAPITAL STRUCTURE IN NIGERIAN QUOTED FIRMS', vol. 8, no. 1, pp. 61-76, 2009.

[22] G. Morri, 'US REITs capital structure determinants and financial economic crisis effects', 2017, doi: 10.1108/JPIF-07-2016-0055.

[23] I. Ghozali, Aplikasi Analisis Multivariate dengan Program IBM SPSS 25, 9th ed. 
Semarang: Universitas Diponegoro, 2018.

[24] K. Hussainey and K. Aljifri, 'Corporate governance mechanisms and capital structure in UAE', J. Appl. Account. Res., vol. 13, no. 2, pp. 145-160, 2012, doi: 10.1108/09675421211254849.

[25] S. Chadha, 'An Empirical Study on Capital Structure in Indian Manufacturing Sector', 2016, doi: $10.1177 / 0972150915619817$.

[26] K. Basu, 'Market Imperfections and Optimal Capital Structure : Evidence from Indian Panel Data', vol. 2, no. 2010, pp. 133-149, 2015, doi: 10.1177/0972150914553509.

[27] B. Alhashel, 'Capital structure of firms when taxes are removed', J. Econ. Adm. Sci., vol. 31, no. 1, pp. 51-63, 2015, doi: 10.1108/jeas-10-2013-0040. 